\title{
TO THE KNOWLEDGE OF THE VELVET ANT GENUS BISCHOFFITILLA LELEJ (HYMENOPTERA: MUTILLIDAE) IN INDONESIA
}

\author{
Danu Dwi Sutanto $^{* 1}$, Kevin A. Williams ${ }^{2}$, Hari Nugroho ${ }^{3}$, and Arkady S. Lelej ${ }^{4}$ \\ ${ }^{1}$ Biology, Ahmad Dahlan University, Yogyakarta, Indonesia \\ ${ }^{2}$ Plant Pest Diagnostics Center, California Department of Food and Agriculture, 3294 Meadowview Road, \\ Sacramento, CA 95832, USA \\ ${ }^{3}$ Museum Zoologicum Bogoriense, Research Center for Biology, Indonesian Institute of Sciences (LIPI), \\ J1. Raya Jakarta-Bogor Km. 46, Cibinong, Bogor 16911, Indonesia \\ ${ }^{4}$ Federal Scientific Center of the East Asia Terrestrial Biodiversity, Far Eastern Branch of \\ Russian Academy of Sciences, Vladivostok-22 690022, Russia \\ *Corresponding author: danu.dwisutanto@gmail.com
}

\begin{abstract}
Seven species of the genus Bischoffitilla Lelej were previously known from Indonesia. Bischoffitilla selangorensis (Pagden, 1934) is newly recorded from Indonesia. Bischoffitilla palaca (Cameron, 1902) is newly recorded from Java, and B. saffica (Zavattari, 1914) from Sumatra. Keys to the Indonesian species of Bischoffitilla are given.
\end{abstract}

Keywords: Java, mutillid wasps, Myrmillinae, Sumatra, Wallace

\begin{abstract}
ABSTRAK
Tujuh spesies dari marga Bischoffitilla Lelej sebelumnya telah diketahui berasal dari Indonesia. Bischoffitilla selangorensis (Pagden, 1934) merupakan catatan baru dari Indonesia. Bischoffitilla palaca (Cameron, 1902) merupakan catatan baru dari Jawa, dan B. saffica (Zavattari, 1914) dari Sumatera. Kunci identifikasi untuk spesies Bischoffitilla dari Indonesia diberikan.
\end{abstract}

Kata kunci: Jawa, tawon mutillid, Myrmillinae, Sumatera, Wallace

\section{INTRODUCTION}

The study of Mutillidae in Indonesia was started by the eminent naturalist Alfred Russel Wallace (Wallacidia Lelej et Brothers, 2008 is a mutillid genus dedicated to him). Alfred Wallace spent several years in the Netherlands-Indies collecting specimens and gathering data regarding geographical distribution of animals (Mickel, 1935). Based on the insect specimens collected by Wallace, Frederick Smith described and recorded 37 species of Mutillidae from the East Indian Islands (Smith, 1858, 1859, 1860a, 1860b, 1861-1862, 1863, 1865, 1879).

Currently, 91 species in 25 genera of mutillid wasps are known from Indonesia (Mickel, 1935; Pagden, 1949; Lelej, 2005; Pagliano et al., 2020). Most of these species were described from the island of Java. Here we summarize data on the genus Bischoffitilla Lelej from Indonesia with one newly recorded species and provide a key to the eight species that are distributed in the islands of Indonesia. 


\section{MATERIALS AND METHODS}

Specimens were photographed using a Leica MC170 HD camera attached to a Leica MC165 C stereoscope.

The following codens are used for collections housing the material studied herein.

BMNH - The Natural History Museum, London, Greater London, U.K.

EMUS - Department of Biology Insect Collection, Utah State University, Logan, Utah, USA.

MZB - Museum Zoologicum Bogoriense, Indonesian Institute of Sciences, Cibinong, Indonesia.

RMNH - Naturalis Biodiversity Center, Leiden, South Holland, the Netherlands.

SKYC - Seiki Yamane Collection of Mutillidae, temporarily deposited in Federal Scientific Center of the East Asia Terrestrial Biodiversity (formerly Institute of Biology and Soil Science), Vladivostok, Russia.

UMSP - University of Minnesota Insect Collection, St. Paul, Minnesota, USA.

\section{RESULTS}

\section{Systematics}

\section{Genus Bischoffitilla Lelej, 2002}

Bischoffitilla Lelej, 2002: 126. Type species: Squamulotilla exilipunctata (Chen, 1957), by original designation.

Squamulotilla: Mickel, 1935: 183.

Diagnosis. MALE. Mandible not widened apically, inner border with two small preapical denticles and larger basal one. Length of flagellomere 1 almost equal to flagellomere 2. Metasomal sternum 2 often with highly elevated median carina. Metasomal sternum 8 (hypopygium) not membranous laterally, with medial carina (tubercle) or lateral carinae (tubercles). FEMALE. Mesopleural suture complete and connecting with mesonotal tubercle; inner margin of mandible with distinct tooth in basal third; metasomal tergum 1 with apicomedial setal spot that sometimes extending to base of tergum 2; and tergum 2 with thick apical setal or cuticular band or medial spot. For additional diagnostic features, see Lelej (2002) .

Species included. The genus Bischoffitilla currently includes 75 described species, 70 of them are known from the Oriental region and five from the Palaearctic (Lelej, 2002 update, 
2005; Williams et al., 2019). Seven species are known from Indonesia: Bischoffitilla aesyca (Cameron, 1902), +; B. deserta (Smith, 1879), +; B. facilis (Smith, 1860), ô; B. muiri

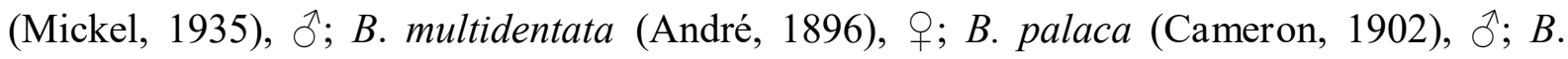
saffica (Zavattari, 1914), + , and in this paper we add newly recorded from Indonesia the eighth species B. selangorensis (Pagden, 1934) (Sumatra).

\section{Key to the species of Bischoffitilla from Indonesia}

Females (unknown for B. facilis, B. muiri, and B. palaca)

1. Propodeum with a transverse row of long vertical teeth at the junction of the posterior and dorsal surfaces

- Propodeum slightly serrate, but without a transverse row of long, vertical teeth at the junction of the posterior and dorsal surfaces

2. Metasomal terga 3-5 with small apicomedial spot of golden setae. Teeth of propodeal transverse row more or less equal in the length. Metasomal tergum 1 with medial spot and metasomal tergum 2 with apical band of silvery or golden setae only, cuticle mostly black beneath markings. Gena without distinct, dentate carina. Posterior propodeal face broadly areolate

B. deserta (Smith)

- Metasomal terga 3-5 without small apicomedial spot of golden setae. Teeth of propodeal transverse row differing in length: median and lateral longest, teeth between them short B. selangorensis (Pagden)

3. Head with vertex largely reddish. Metasomal markings formed of silvery setae

B. aesyca (Cameron)

- Head entirely black. Metasomal markings formed of pale-yellow setae 4

4. Propodeum dorsally with prominent medial tooth. Metasomal terga 4-5 with medial spot of pale setae B. saffica (Zavattari)

- Propodeum dorsally without prominent medial tooth, at most with transverse, slightly serrate carina at posterior margin. Mesoscutum with distinct, medial, longitudinal carina. Scape and tibiae blackish

B. multidentata (André) 
Males (unknown for B. aesyca, B. deserta, B. multidentata, B. saffica, and B. selangorensis)

1. Fore wing with two submarginal cells. Hypopygium armed with two oblique raised carinae baso-laterally B. palaca (Cameron)

- Fore wing with only one submarginal cell. Hypopygium unarmed or with obscure medial arcuate swelling basally 2

2. Metasomal terga 2-4 each with yellow apicomedial cuticular spot. Hypopygium with medial arcuate swelling

B. muiri (Mickel)

- Only metasomal tergum 2 with yellow apical cuticular band. Hypopygium flat, without arcuate swelling

B. facilis (Smith)

\section{Catalogue of the species}

1. Bischoffitilla aesyca (Cameron, 1902). Figs 1, 2.

Mutilla aesyca Cameron, 1902: 208, q (Malaysia: "Borneo").

Squamulotilla aesyca: Mickel, 1935: 194, + (Malaysia: Sarawak, Sabah), Indonesia (Borneo: West Kalimantan); Pagden, 1949: 226, o (West Java).

Bischoffitilla aesyca: Lelej, 2005: 23.

Diagnosis. FEMALE. Propodeum slightly serrate, without transverse row of long, vertical teeth at the junction of the posterior and dorsal surfaces. Median spot on metasomal tergum 1 and apical band on metasomal tergum 2 white, maculations formed only by silvery setae. Metasomal tergum 3 entirely with black setae. Head largely ferruginous; apical margin of metasomal tergum 5 with band of appressed, silvery setae. MALE. Unknown.

Material examined. INDONESIA: Borneo [West Kalimantan], Pontianak, 1q, leg. F. Muir (UMSP, compared with type by C.E. Mickel in 1931).

Distribution. Indonesia (West Java, West Kalimantan), Malaysia (Sarawak, Sabah) (Mickel, 1935).

2. Bischoffitilla deserta (Smith, 1879). Figs 3, 4.

Mutilla deserta Smith, 1879: 200, + "Celebes".

Squamulotilla deserta: Mickel, 1934: 109, + (Philippines, Luzon); Pagden, 1949: 225, (Java, Kangean Islands).

Bischoffitilla deserta: Lelej, 2005: 25. 
Diagnosis. FEMALE. Propodeum with a transverse row of three long vertical teeth at the junction of the posterior and dorsal surfaces. Median spot on metasomal tergum 1 and apical band of metasomal tergum 2 pale, the maculations formed by silvery or golden pubescence only, cuticle mostly black beneath markings. Posterior margin of gena without a distinct, dentate carina. Metasomal terga 3-5 each with a small, apical, median spot of pale setae. Posterior propodeal face broadly areolate. MALE. Unknown.

Material Examined. INDONESIA: West Java: Cibinong, Bogor, 6,494361 ${ }^{\circ} \mathrm{S}$ 106,852545 ${ }^{\circ}$ E, 27.XI.2017, 1 q, leg. D. Sutanto (MZB); Jasinga near Bogor, 5.XI.1985, $1+$, leg. Sk. Yamane (SKYC). PHILIPPINES: Rizal, Antipolo, 6.IX.1952, 1q, leg. Townes Family (EMUS).

Distribution. Indonesia (Sulawesi, Kangean Islands, Java), Philippines (Luzon) (Mickel, 1935; Pagden, 1949; Lelej, 2005).

3. Bischoffitilla facilis (Smith, 1860). Figs 5, 6.

Mutilla facilis Smith, 1860: 76, §̊ ("Makassar").

Squamulotilla facilis: Mickel, 1935: 186, §̂.

Bischoffitilla facilis: Lelej, 2005: 26.

Diagnosis. MALE. Fore wing with one submarginal cell. Lateral margins of pronotum prominently angulate medially. Only metasomal tergum 2 with a narrow, pale yellow, integumental stripe at the apical margin. Hypopygium flat, lacking basal carina or swelling. FEMALE. Unknown.

Material examined. INDONESIA: Southwest Sulawesi, Gn. Bulusaraung, near Camba Malawa, Malaise trap 3, 750 m, 7.II-28.III.1995, 1ð̊, leg. C.v. Achterberg and Y. Yasir (RMNH).

Distribution. Indonesia (Sulawesi) (Mickel, 1935).

4. Bischoffitilla muiri (Mickel, 1935). Figs 7, 8.

Squamulotilla muiri Mickel, 1935: 186, §̊ ("Java, Buitenzorg" [Cibinong]). Bischoffitilla muiri: Lelej, 2005: 27.

Diagnosis. MALE. Fore wing with one submarginal cell. Lateral margins of pronotum prominently angulate medially. Metasomal terga 2-4 with a narrow, pale yellow, integumental stripe at the apical margin, not extending to the lateral margins. Hypopygium basally with obscure raised arch-like medial shelf. FEMALE. Unknown.

Material examined. INDONESIA: Java, Goenoeng Gedeh, III.1911, 1ð̊, leg. E. Jacobson (RMNH).

Distribution. Indonesia (Java) (Mickel, 1935). 


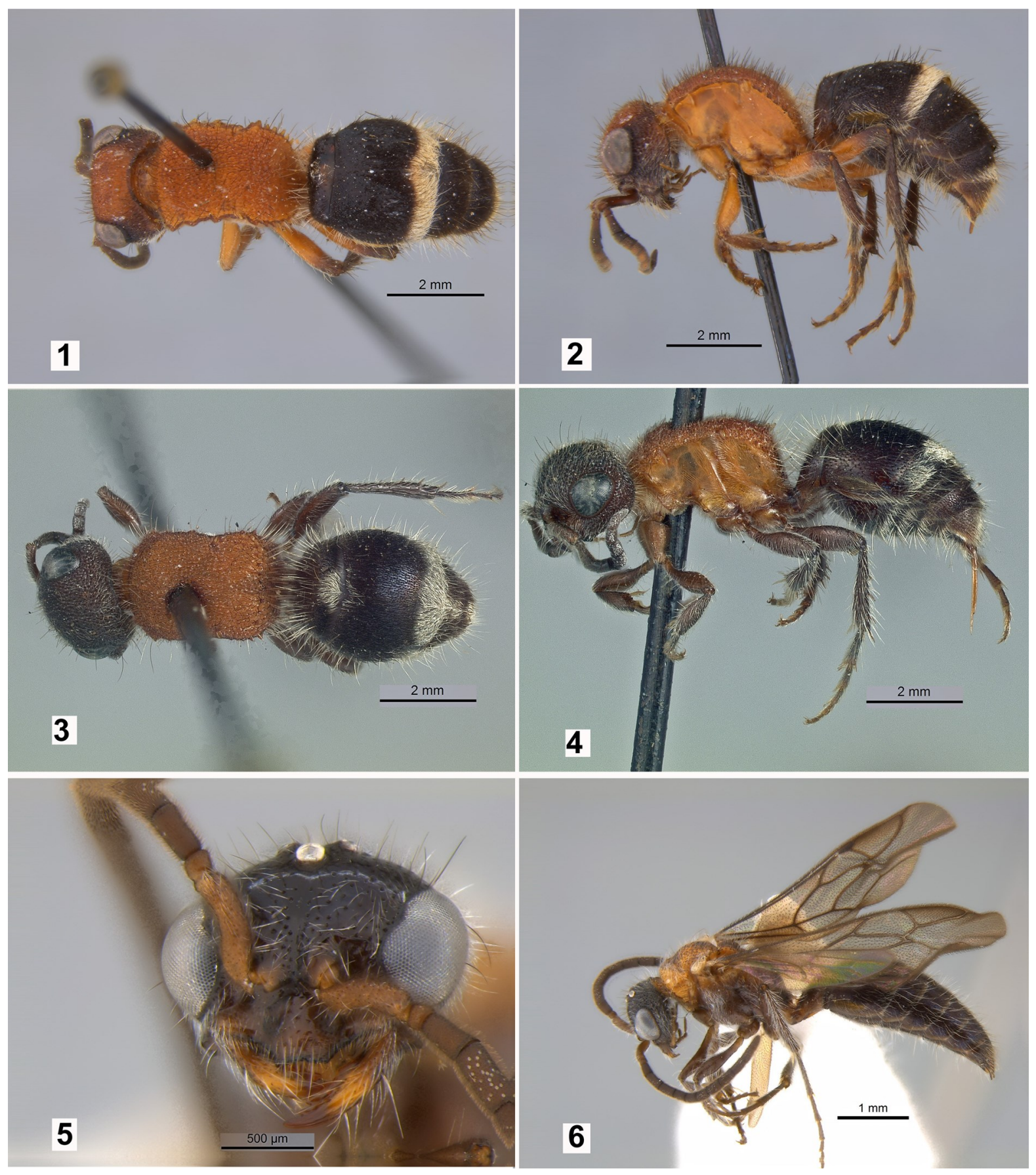

Figures 1-6. Photographs of : 1, 2. Bischoffitilla aesyca, female; 3, 4. B. deserta, female; 5, 6. B. facilis, male; 1, 3. Habitus, dorsal view; 2, 4, 6. Habitus, lateral view; 5. Head, frontal view. 
5. Bischoffitilla multidentata (Andre, 1896). Figs 9, 10.

Mutilla multidentata André, 1896: 76, q ("Si-Rambé" [North Sumatra], "Perak" [Malaysia]).

Odontomutilla multidentata: Zavattari, 1914: 68, + (Simalu [=Simeulue Island, westward of Sumatra]).

Squamulotilla multidentata: Mickel, 1935: 193, + .

Bischoffitilla multidentata: Lelej, 2005: 27.

Diagnosis. FEMALE. Propodeum slightly serrate, without a transverse row of long, vertical teeth at the junction of the posterior and dorsal surfaces. Median spot on metasomal tergum 1 and apical band of metasomal tergum 2 white. Propodeum dorsally without a median tooth, at the most with a transverse, slightly serrate carina at the posterior margin. Lateral margins of mesonotum conspicuously dentate. Mesonotum with a distinct, median, longitudinal carina. MALE. Unknown.

Material examined. INDONESIA: North Sulawesi, Dumoga-Bone National Park, ca.

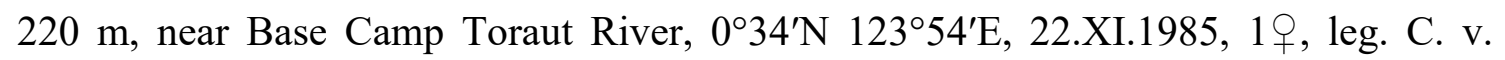
Achterberg (RMNH).

Distribution. Indonesia (Simeulue, Sulawesi, Sumatra), Malaysia (Perak) (André, 1896; Zavattari, 1914; Mickel, 1935).

6. Bischoffitilla palaca (Cameron, 1902). Figs 11, 12.

Mutilla palaca Cameron, 1902: 80, ठ̊ ("Kuching" [Malaysia: Sarawak]).

Squamulotilla palaca: Mickel, 1935: 188, §̋.

Bischoffitilla palaca: Lelej, 2005: 28; Lo Cascio, 2015: 546 (Sumatra).

Diagnosis. MALE. Fore wing with two submarginal cells. Lateral margins of pronotum not angulate medially. Metasomal tergum 2 with a narrow, pale yellow, integumental stripe at the apical margin, not extending to the lateral margins. Hypopygium basally with two oblique raised carinae. FEMALE. Unknown.

Material examined. INDONESIA: West Java, West Priangan, 1800 to 2400 ft., 412.XI.1941, 10̂, leg. J.M. A.V. Groenendael (RMNH).

Distribution. Indonesia (Sumatra, Java), Malaysia (Sarawak) (Cameron, 1902).

Remarks. This species is newly recorded from Java.

7. Bischoffitilla saffica (Zavattari, 1914). Figs 13, 14.

Odontomutilla saffica Zavattari, 1914: 68, ๆ ("Celebes: Minahassa, Pangie").

Squamulotilla saffica: Mickel, 1935: 193, ㅇ (Sulawesi).

Bischoffitilla saffica: Lelej, 2005: 28. 


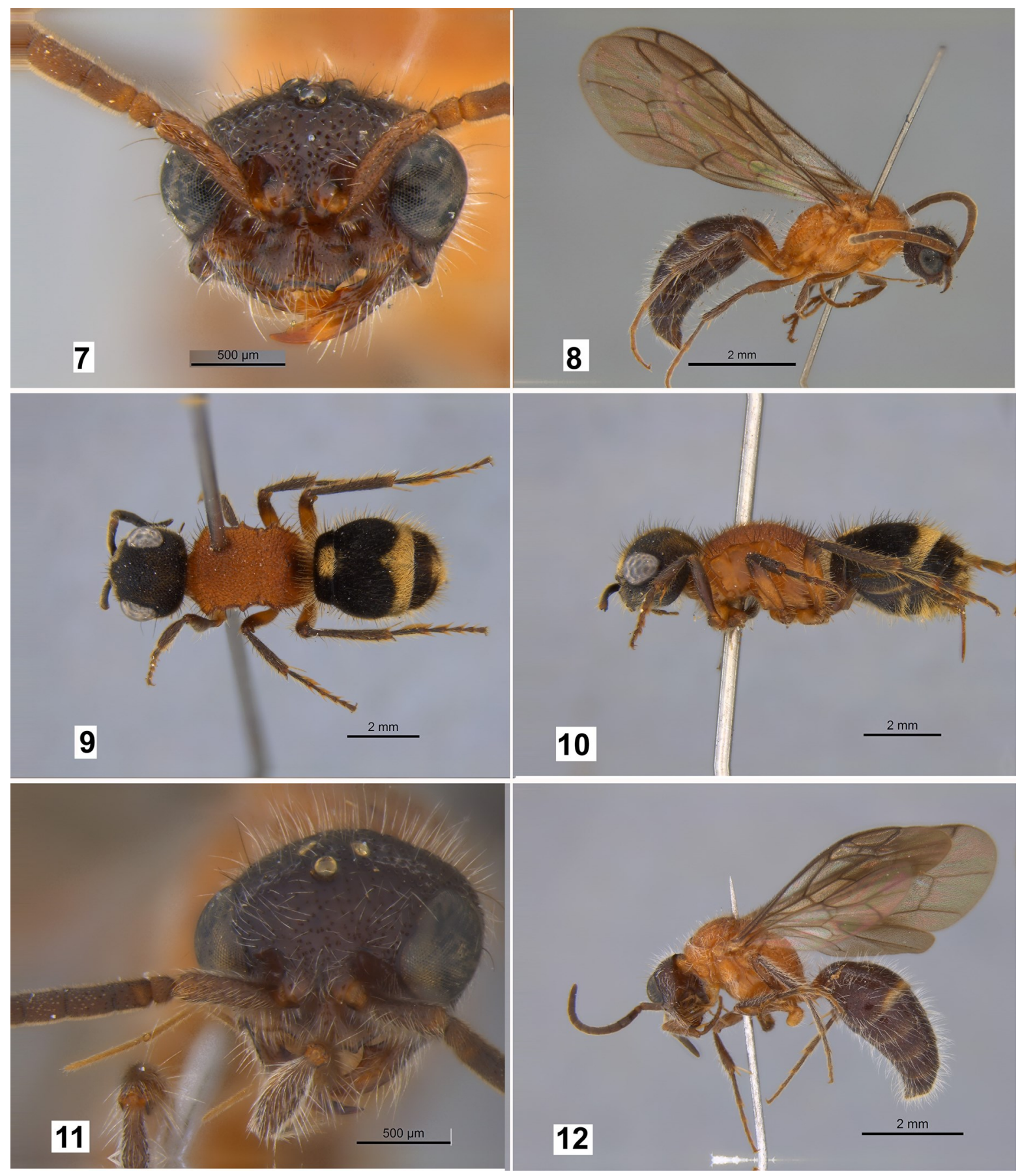

Figures 7-12. Photograph of: 7, 8. Bischoffitilla muiri, male; 9, 10. B. multidentata, female; 11, 12. B. palaca, male; 7, 11. Head, frontal view; 8, 10, 12. Habitus, lateral view; 9. Habitus, dorsal view.

Diagnosis. FEMALE. Propodeum slightly serrate, without a transverse row of long, vertical teeth at the junction of the posterior and dorsal surfaces. Median spot on metasomal tergum 1 and apical band of metasomal tergum 2 white. Propodeum dorsally 
with a prominent, median tooth. Metasomal terga 4-5 with a median spot of pale pubescence. MALE. Unknown.

Material examined. INDONESIA: West Sumatra, Payakumbuh, Harau Valley, 1000 m, 9-29.X.1991, 19, leg. A. Riedel (SKYC); Northeast Sulawesi, 47 km WSW Kotamobagu Dumoga-Bone National Park, Toraut (base camp), 211 m, IV.1985, G.R. Else, Project Wallace (BMNH).

Distribution. Indonesia (Sulawesi, Sumatra).

Remarks. This species is newly recorded from Sumatra.

8. Bischoffitilla selangorensis (Pagden, 1934). Figs 15, 16.

Squamulotilla selangorensis Pagden, 1934: 452, + ("Bukit Kutu" [Malaysia, Selangor]); Mickel, 1935: 196.

Bischoffitilla selangorensis: Lelej, 2005: 29.

Diagnosis. FEMALE. Head black, closely punctate, mandible ferruginous, clypeus, scape and pedicel pale ferruginous, antennal scrobes strongly carinate above. Gena posterad with weak irregular carina. Mesosoma dorsally densely confluently punctate with median pronounced ridge from pronotal area to median spine of propodeal brow; propodeal brow with strong median spine, denticulate laterally, lateral propodeal margin strongly spinose. Metasoma with median apical pale golden spot on tergum 1 and pale golden apical band on tergum 2. MALE. Unknown.

Material examined. INDONESIA: West Sumatra, Payakumbuh, Harau Valley, 1000 m, 9-29.X.1991, 1, leg. A. Riedel (SKYC). MALAYSIA: Selangor, Bukit Kutu, 31.I.1930 (Holotype, BMNH).

Distribution. Indonesia (new record) (Sumatra), Malaysia (Selangor) (Pagden, 1934). 

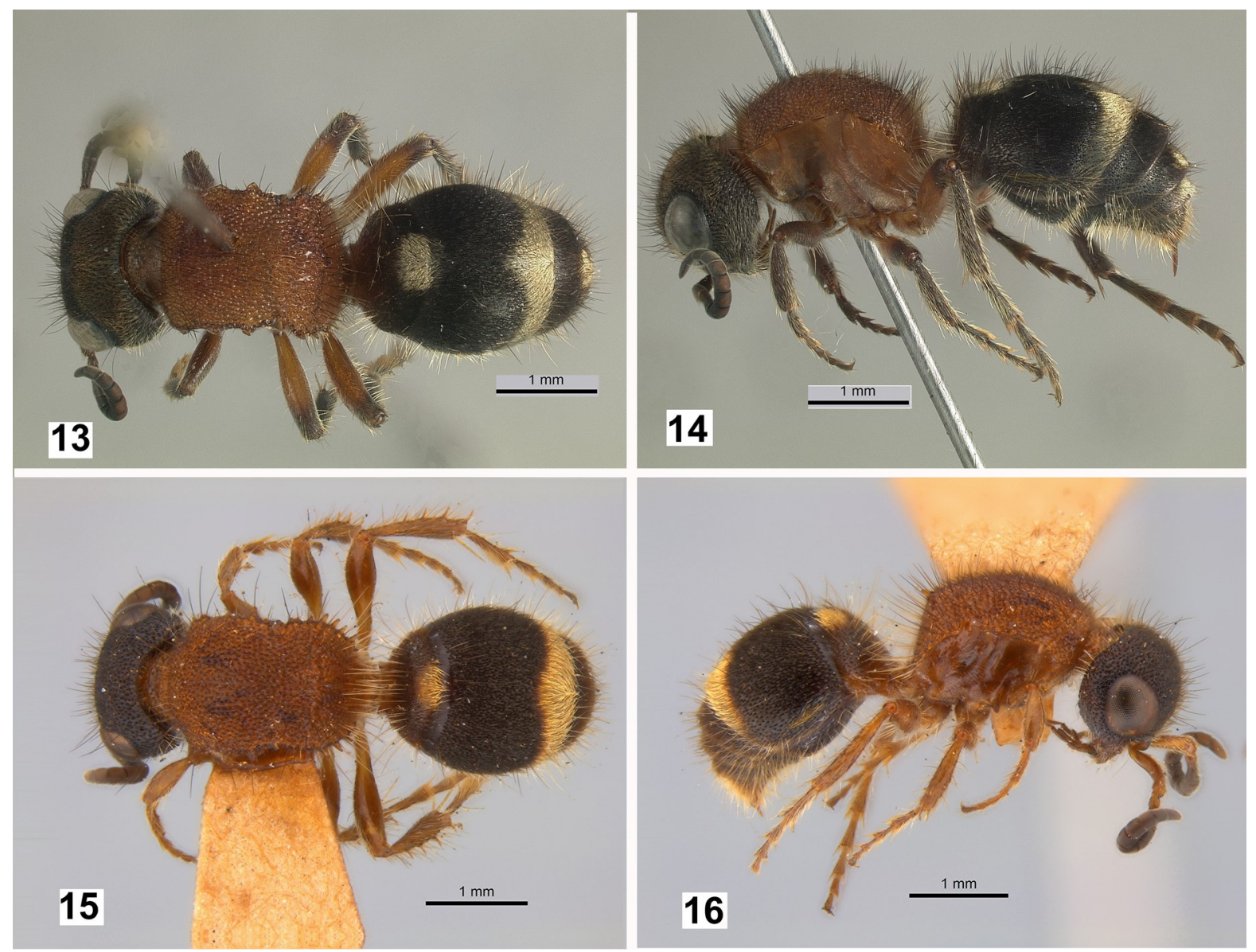

Figures 13-16. Photographs of : 13, 14. Bischoffitilla saffica, female; 15, 16. B. selangorensis, female; 13, 15. Habitus, dorsal view; 14, 16. Habitus, lateral view.

\section{DISCUSSION}

The current number of mutillid species recorded from Indonesia is 93 species in 25 genera, but the true diversity is likely much higher. Recent faunistic studies of velvet ants in other countries have raised their known species diversity. In Thailand, for example, the number of recorded species raised from 33 to 63 (Williams et al., 2019). Furthermore, 68 velvet ant species have been recognized in the Malaysian portion of Borneo (Lelej, 2005); many of these species likely also occur in the Indonesian provinces of East, North, South, and West Kalimantan. A similar situation occurs on the island of New Guinea, where 15 species are known from Papua New Guinea that may also be found in the Indonesian provinces of Papua and West Papua. The true diversity of Indonesia may easily surpass 200 species after further investigation. 
As seen above, many velvet ant species are known from a single sex: males only or females only. Of the 93 species in Indonesia, fewer than 20 are recognized from both sexes (Lelej, 2005). Being composed of multiple separated islands, Indonesia provides a unique opportunity for associating males and females of various species because the potential matches can be more easily narrowed down. For example, based on its distribution in Sulawesi, the male of Bischoffitilla facilis (Smith, 1860) can be narrowed down to a match with either B. multidentata (André, 1896) or B. saffica (Zavattari, 1914). Further collecting efforts and documentation of species from specific islands and localities will be vital for better understanding the diversity and variation of these sexually dimorphic wasps.

\section{ACKNOWLEDGEMENTS}

We thank the curators and collection managers who provided material for this study, including Robin Thomson (UMSP), Frederique Bakker (RMNH), Gavin Broad (BMNH), James Pitts and David Wahl (EMUS).

\section{REFERENCES}

André, E. 1896. Étude sur les Mutillides existant dans les collections du Musée civique de Gênes. Annali del Museo Civico di Storia Naturale di Genova ser. 2, 17: 66-104.

Cameron, P. 1902. On some new genera and species of Hymenoptera (Ichneumonidae, Chrysididae, Fossores, and Apidae). The Entomologist, 35: 108-111, 179-183, 206-208, 237-241, 263-264, 312-315.

Lelej, A.S. 2002. Catalogue of the Mutillidae (Hymenoptera) of the Palaearctic Region. Vladivostok: Dalnauka: $172 \mathrm{pp}$.

Lelej, A.S. 2005. Catalogue of the Mutillidae (Hymenoptera) of the Oriental Region. Vladivostok: Dalnauka: 252 pp.

Lo Cascio, P. 2015. Worldwide checklist of the island mutillid wasps (Hymenoptera Mutillidae). Biodiversity Journal, 6(2): 529-592.

Mickel, C.E. 1934. Mutillidae of the Philippine Islands (Hymenoptera). The Philippine Journal of Science, 54(1): 91-219+ pl. 1 .

Mickel, C.E. 1935. The mutillid wasps of the islands of the Pacific ocean (Hymenoptera: Mutillidae). Transactions of the Royal Entomological Society of London, 83(2): 177-312.

Pagden, H.T. 1934. New species of Mutillidae (Hymenoptera, Vespoidea) from the Malay Peninsula. Journal of the Federated Malay States Museums, 17: 419-457.

Pagden, H.T. 1949. Descriptions and records of Austro-Malaysian Methocidae and Mutillidae (Hymenoptera). Transactions of the Royal Entomological Society of London, 100(8): 191-231.

Pagliano, G., Brothers, D.J., Cambra, R., Lelej, A.S., Lo Cascio, P., Matteini Palmerini, M., Scaramozzino, P.L., Williams, K.A. \& Romano, M. 2020. Checklist of names in Mutillidae (Hymenoptera), with illustrations of selected species. Bollettino del Museo regionale di Scienze naturali di Torino, 36(1-2): 5-425.

Smith, F. 1858. Catalogue of hymenopterous insects collected at Celebes by Mr. A.R. Wallace. Journal of the Proceedings of the Linnaean Society, Zoology, 3: 4-27. 
Smith, F. 1859. Catalogue of hymenopterous insects collected by Mr. A.R. Wallace at the Islands of Aru and Key. Journal of the Proceedings of the Linnaean Society, Zoology, 3: 132-178.

Smith, F. (1861)1860a. Descriptions of new species of hymenopterous insects collected by Mr. A.R. Wallace at Celebes. Journal of the Proceedings of the Linnaean Society, Zoology, 5 (published as suppl. to vol. 4): 57-93.

Smith, F. (1861)1860b. Catalogue of hymenopterous insects collected by Mr. A.R. Wallace in the islands of Bachian, Kaisaa, Amboyna, Gilolo, and at Dory in New Guinea. Journal of the Proceedings of the Linnaean Society, Zoology, 5 (published as suppl. to vol. 4): 93-143, pl. I.

Smith, F. 1861-1862. Catalogue of hymenopterous insects collected by Mr. A.R. Wallace in the islands of Ceram, Celebes, Ternate, and Gilolo. Journal of the Proceedings of the Linnaean Society, Zoology, 1861, 6: 36-48, pl. I; 1862, 6: 49-66.

Smith, F. 1863. Catalogue of hymenopterous insects collected by Mr. A.R. Wallace in the islands of Mysol, Ceram, Waigiou, Bouru and Timor. Journal of the Proceedings of the Linnaean Society, Zoology, 7: 6-48.

Smith, F. 1865. Descriptions of new species of hymenopterous insects from the Islands of Sumatra, Sula, Gilolo, Salwatty, and New Guinea, collected by Mr. A.R. Wallace. Journal of the Proceedings of the Linnaean Society, Zoology, 8: 61-94, pl. IV.

Smith, F. 1879. Descriptions of New Species of Hymenoptera in the Collection of the British Museum. London: Taylor and Francis: XXI $+240 \mathrm{pp}$.

Williams, K.A., Lelej, A.S., Okayasu, J., Borkent, C.J., Malee, R., Thoawan, K. \& Thaochan, N. 2019. The female velvet ants (aka modkhong) of Southern Thailand (Hymenoptera: Mutillidae), with a key to the genera of Southeast Asia. Zootaxa, 4602(1): 1-69.

Zavattari, E. 1914. Mutille Austro-Malesi. Bolletino della Società Entomologica Italiana, 45: 61-114. 